\section{EASTERN BLUEBIRD BOXES IN ONTARIO}

L. A. SMITH, 481 Vaughan Road, Apt. 207, Toronto, Ontario M6C 2P6

My trail consists of 500 boxes stretching across 11 townships: Caledon, Albion, Mono, Mulmur, Osprey, Tosorontio, King, Uxbridge, Reach, Cartwright and Darlington.

In 1976 we had 140 good nestings and expected 170 in 1977. As it happened we had only 100 good broods. The blame can be placed on the deep snow that plagued the eastern United States last winter. It was definitely a set-back year - the first since bluebirds began to nest in my houses in 1970

I wish I could say we have found ways to counteract vandalism but this is not so. This was the worst year for shooting and destruction since the project began. A singing male was shot dead while sitting on top of Box 10 in the Drumlin-Esker Park in the Hockley Valley. A family of Tree Swallows was killed by rifle fire in Box 268 in Mulmur Township. Trail bikes are entering many fields and cruising around at high speeds with a terrific amount of noise. Some boxes are broken off and left lying on the ground. Other units are stolen. Some houses get doors pulled off and some have their roofs pried open. In spite of this, one new area in Mono Township raised five successful broods from six boxes and with no interference during the nesting season.

The entire trail is being reorganized. More boxes are going into the good areas while the poorer regions are being abandoned. Bluebirds like dry sandy soil, sparse vegetation, old rchards, worn-out farms, forest glades and Christmas tree plantations.

Procupines ate a lot of the plywood on our boxes, so, for 1978 we are trying to put metal around all the posts. A big ob but progressing satisfactorily.

\section{THIRD RECORD OF HARLEQUIN DUCK AT CHURCHILL, MANITOBA}

KEN WALTON and DONNA I MacLACHLAN, P.O. Box 2, Dauphin, Manitoba R7N 2T9

On July 2, 1977, three female Harlequin Ducks were sighted by the authors at the north end of Cape Merry, Churchill, Manitoba. The birds were in rough water, approximately 50 yards off the rocky shoreline. They were first spotted about 10:00 a.m. and observed for about 20 minutes in full sunlight with $7 \times 35$ and $9 \times 35$ binoculars.

At noon on the same day, Ken and Bonnie Chartier, a local birder, went back to Cape Merry and found four females and three males.

The following descriptions were recorded: Female - plumage a sootybrown with white patch areas, one situated behind the eye, one below the eye, and one in front of the eye, no wing-patch, and size similar to a female Black Scoter. Male - plumage slate-blue with chestnut sides and a striking pattern of white spots and stripes edged with black on the head, neck and chest; wings are dark slate, with a bluish chest.

This is the third record for the Churchill area, all at Cape Merry: single males were seen from July 11 to 14,1970 , and on July $11,1971 .{ }^{3}{ }^{1}$ It was not reported by Jehi and Smith. ${ }^{2}$ McNicholl notes only 10 records for the province, no more than three birds being observed at any one time. ${ }^{3}$

'FORSTER, A. 1972. Winter Wren, Sprague's Pipit and other records at Churchill. Blue Jay 30:27-28.

${ }^{2}$ JEHL, J. R., and B. A. SMITH, 1970. Birds of the Churchll region, Manitoba. Spec. Pub. 1, Manitoba Mus. of Man and Nature, Winnipeg, Manitoba. 87 pp.

${ }^{3} \mathrm{MCNICHOLL}, \mathrm{M}$. K. 1973. Records of the Harlequin Duck in Manitoba and adjacent regions. Blue Jay 31:150-152. 